\title{
Effect of Basic Life Support Training on Knowledge and Practice of Preparatory School Teachers in Sheben Elkom City, Menoufia Governorate,Egypt
}

Safa H. Al kalash*

Family medicine, Faculty of Medicine, Menoufia University

\begin{abstract}
:
Background: Early recognition and immediate bystander cardiopulmonary resuscitation are critical determinants of survival after out-of-hospital cardiac arrest. Presence of qualified teachers who can detect any health problem and can give first aid for emergencies in schools is a very important issue. Objective: It was to assess knowledge and practice of preparatory schools' teachers before and after application of Basic Life Support training program in Sheben Elkom city, Menoufia governorate.

Methods: A sample of 300 teachers participated in the study; they were selected by simple random sampling technique. They had completed a pretest through using a questionnaire to assess their knowledge while their practice was assessed through a checklist followed by application of BLS training program for them. Their knowledge and practice were re-evaluated 3 months later by same tools.

Results: A sample of 300 teachers had participated in the study; male sex was predominant (79.7\%) and middle socioeconomic status constituted (84.3\%). Post-test mean knowledge and practice scores $(10.11 \pm 1.8) \&(7.46 \pm 1.4)$ respectively were higher than pretest mean knowledge and practice scores $(2.04 \pm 2.4) \&(3.44 \pm 0.85)$ respectively. There was a highly statistically significant difference in their knowledge and practice scores pre and post BLS training program (p value < $0.001)$ for each.
\end{abstract}

Conclusion: Current Basic Life Support training program was successful in enhancing knowledge and practice of preparatory school teachers.

Key words: Basic Life Support, knowledge, Practice, Teachers

\section{Introduction:}

Children spend most of the time in school under direct supervision of teachers. They are also exposed to various types of epidemiological factors in the school, which influence their present and future state of health. ${ }^{1}$ Cardiac arrest (CA) is an immediate medical emergency situation that happens outside hospital settings in $70 \%$ of the cases and carries a high level of mortality risk. ${ }^{2}$

Despite the advancement in preventative and resuscitation medicine, sudden cardiac arrest (SCA) still remains a significant health problem. The SCA can be caused by either cardiac or non-cardiac etiologies, can be witnessed or unwitnessed and can also occur inside or outside a hospital. ${ }^{3}$ The SCD is statistically uncommon in the young, but its dramatic presentation and cascading effects in the family and community make it a newsworthy event. ${ }^{4}$

The frequency of cardiac arrest is about 3 times higher among teachers and school personnel than students. ${ }^{5}$ Therefore, teachers and school personnel have responsibilities to physical health of students. ${ }^{6}$ For this purpose

*Corresponding author: E-mail: dr_safa4@yahoo.com 
and for preparing teachers to meet the risky conditions in school, training them of them is considered a critical and important issue. ${ }^{7}$

Basic Life Support (BLS) is a rapid identification of signs of cardiac arrest, stroke, foreign body airway obstruction and starting basic steps to maintain circulation and breathing. ${ }^{8}$ There are four links in the chain of survival: early recognition and call for help, early performance of cardiopulmonary resuscitation, early defibrillation, and postresuscitation care. ${ }^{9}$ Immediate cardiopulmonary resuscitation (CPR) after collapse can double or triple survival rates. In contrast, if CPR is delayed survival chances decrease by $7-10 \%$ for every minute passing by. ${ }^{10}$

There are two critical components to successful resuscitation: 1-Presence of a person with knowledge to perform CPR. 2- The successful performance of CPR at the earliest possible time. In order to increase the likelihood of having a CPR-skilled person present at the cardiac event, there must be an adequate number of people trained in the community. ${ }^{11}$ It can be given by health care providers as well as bystander. Recent studies show that the survival of out-of-hospital cardiac arrest (CA) is determined by immediate cardiopulmonary resuscitation
(CPR) provided by bystander if it's given in a right way well in time. ${ }^{12}$

It has been recommended by the American Heart Association (AHA) in 2004, to train all teachers and students on CPR, moreover, in agreement with the guidelines of the International Liaison Committee on Resuscitation (ILCOR), it has been strongly recommended including Basic Life Support (BLS) in the school curriculum

There are many educational methods that are available for teachers to use in various conditions. In educational settings, explanatory methods are the most common for teaching the concepts and lessons. In these methods, teacher transfers information to learners through the print media and lecture. ${ }^{13}$ Among educational methods, the lecture method is inevitable in some cases because it is a suitable means to present basic information and transfer science and even is the most appropriate teaching method in some circumstances. ${ }^{14}$ This work aimed to assess knowledge and practice of preparatory schools' teachers before and after application of Basic Life Support training program in Sheben Elkom city - Menoufia governorate.

\section{Methods:}

An official permission letter was obtained and directed to general director of education in 
Sheben Elkom city, Menoufia governorate. Written consent was obtained from all participants after simple and clear explanation of the research objectives. The study was an intervention study which was applied to preparatory school teachers in Sheben Elkom city, Menoufia governorate.

The sample size was calculated using EPI-INFO program version (7) depending on the total number of teachers in preparatory schools (2017/2018) in Sheben Elkom city during the period of the study which was 1327 teachers. The estimated sample size was 300 teachers. Four preparatory schools were selected by simple random sampling technique; participants were chosen by the same technique and proportionally allocated according to total number of teachers in each school.

The data were collected by attending the schools twice weekly for about 5 months. During period of the study which started from beginning of October 2017 to end of February 2018. A pilot study was undergone in context of time frame one month before beginning of the study through which the study was conducted for 31 preparatory school teachers in the selected schools. The questionnaire was pretested and some useful modifications in language were performed to be more understandable by the participants based on the feedback from the pilot study. Also, time needed for completing its filling was determined. From the pilot study educational program, duration and place for its conduction were also assessed.

The participants were subjected to the socioeconomic status scale $^{15}$ which consisted of; level of education for him/her, his wife/her husband, his/her work and his wife's/her husband's work, computer use, per capita income, family size, crowding index, sewage disposal and refusal disposal).

Socioeconomic level was classified into low (score < 40\%), middle (score 40-70\%) and high (score $\geq 70$ ) depending on the quartiles of the score calculated. A wellstructured self-designed validated questionnaire was used to assess their knowledge about Basic Life Support (BLS) before application BLS training program for them and this questionnaire consisted of 13 multiple choice questions about BLS such as; In terms of the CPR sequence, what is true?/Which of the following is true about pulse check?/What is recommended regarding chest compressions? / In case of a cardiac arrest, the first thing that needs to be done is? Then teachers' practice of ${ }^{n}$ BLS was assessed through using a pre-designed 
checklist. A lecture about basic life support was conducted for them in the classroom and sometimes in the school theater and its duration was about one and a half hour.

The lecture was designed according to American Heart Association guideline 2015.Followed by hand on training; as the participants were sub-grouped into 15 groups each group consisted of about 20 participants and the training sessions were applied for 3-4 groups weekly for 4 weeks and each group was trained using a manikin/simulator about how to perform an effective CPR, how to use AED effectively also they were trained how to help anyone during choking. Then three months after application of the program they were subjected to the same questionnaire/ checklist to detect their level of knowledge/ practice about BLS.

Regarding the used questionnaire equal marks were given for each question and the scores were converted to percentage scale for their knowledge about BLS. A score of $<30 \%$ was considered as (Very poor), $>30 \%$ to $45 \%$ was considered as (Poor), > $45 \%$ $55 \%$ was considered as (An average), $>55 \%$ to $65 \%$ was considered as (Good), $>65 \%$ to $75 \%$ was considered as (Very good) and $>75 \%$ was considered as (An excellent). ${ }^{16}$
The participant's practice was assessed by a checklist which consisted of 10 items including; assessment of scene safety, victim response, breathing and pulse, performance of effective chest compression with adequate depth by rate 30 compression to 2 breaths for 5 cycles, usage of AED, effective teamwork, abdominal and chest thrust in case of chocking, A score of $<30 \%$ was considered as (very poor), $>30 \%$ to $45 \%$ was considered as (poor), $>45 \%$ - 55\% was considered as (an average), $>55 \%$ to $65 \%$ was considered as (good), $>65 \%$ to $75 \%$ was considered as (very good) and $>75 \%$ was considered as (an excellent). ${ }^{16}$

\section{Statistical design and analysis:}

Main study variables were as follow: Independent variables including age, gender, residency, education level and work of his or her partner and socioeconomic status of the participants. Dependent variables included knowledge, attitude and practice of the participants. Statistical presentation and analysis of the present study was conducted with SPSS V.20. Data were expressed into two phases:

I - Descriptive phase included the following:-

1- Mean value and Standard Deviation [SD]: for quantitative data

2- Frequency and percentage for qualitative date 
II Analytic phase included the following:-

- Paired T test: for comparison of two independent quantitative variables normally distributed.

- P-value >0.05 was considered statistically non significant.

- P-value <0.05 was considered statistically significant.

- P-value<0.001 was considered statistically highly significant.

\section{Results:}

The mean age of the studied groups was $40.1 \pm$ 5.7 and male sex predominance $(79.7 \%)$ among the participants. $55.7 \%$ of them were living in urban areas and (54.3\%) of their wives had high educational level and (73.5\%) of their wives were (housewives). Middle socioeconomic status constituted $(84.3 \%)$ of the participants.

There was a highly statistically significant difference in the participants' knowledge about BLS before and after application of BLS educational session ( $\mathrm{P}$ value $<0.001)$ as $(69.3 \% \& 27.3 \%)$ of them had had very poor and poor knowledge respectively before conducting the educational session for them compared to (37\% \& $23.7 \%)$ of them had an excellent and very good knowledge respectively after application of the educational session. Percentage of correct multiple choice questions (MCQs) varied according to type of knowledge; for example, there was higher knowledge regarding basic questions such as calling for help immediately when seeing a victim had cardiac arrest as percentage of correct answer represented $(39.6 \% \& 95 \%)$ of the participants' answers before and after conduction of the educational session respectively while there was a lower knowledge regarding the more technical skill questions such as the use of Automated External Defibrillator (AED) $(8.3 \%$ \& $66 \%)$ of the participants' answers before and after conduction of the training program respectively.

There was a highly statistically significant difference in the participants' BLS practice before and after application of BLS training program $(\mathrm{P}$ value $<0.001)$ as $(62.7 \%$ $\& 37.3 \%$ ) of them had had very poor and poor practice respectively before conducting BLS training program for them compared to (50.3\% \& 25.7\%) had good and Excellent practice respectively after application of BLS training program.

\section{Discussion:}

The result of present study had shown that $(69.3 \%$ and $27.3 \%)$ of them had had very poor and poor knowledge respectively before conducting BLS educational program for them. This result was parallel to the results of studies conducted by Ghrayeb et $\mathrm{al}^{12}$ in Palestine and the studies done by Alharbi et al 
17 and Al Enizi et al, ${ }^{18}$ in Saudi Arabia. Also, another study was conducted by Lockey et $\mathrm{al}^{19}$ in the United Kingdom. The assessment tools employed in the studies was not identical but contained similar items such as knowledge of the technique and sequence of steps while performing CPR; hence the findings are comparable.

Also, the results showed that $(69.3 \%$ and $27.3 \%$ ) of them had had very poor and poor knowledge respectively before conducting the educational session for them compared to (37\% and $23.7 \%$ ) of them had an excellent and very good knowledge respectively after application of the educational session with a highly statistically significant difference in their knowledge score before and after application of the training program ( $\mathrm{p}$-value $<0.001)$.

This result was similar to results of a study was conducted by Onyeaso ${ }^{20}$ which revealed that level of pre-training knowledge was $8.9 \%$ compared to post training knowledge of $88.6 \%$. The knowledge difference between pre and post training in CPR was statistically significant $(\mathrm{p}<0.05)$.

The current study had shown that post-test mean knowledge score $(10.11 \pm 1.8)$ was higher than pretest mean knowledge score (2.04 \pm 2.4 ). These findings were consistent with the findings of kabina ${ }^{(21)}$ who conducted a quasi- experimental study to evaluate the effectiveness of planned teaching Program regarding Basic Life Support (BLS) at selected nursing college, Bhubaneswar, Odisha, findings showed that the Post-test Mean was (13.4) was higher than Pretest Mean (9.12).

Similar findings were reported by Goswami $^{22}$ who found that the mean of post test knowledge score $(14.12 \pm 1.15)$ was higher than the mean of pre test knowledge score (7.19 \pm 2.00$)$. Further, our study showed that knowledge varied according to type of question; for example, there was higher knowledge on basic questions as (39\%) of teachers knew that calling for help must be immediately and (35\%) of them knew that chest rise was the right way to confirm if air has reached lungs when doing rescue breaths, $(34.4 \%)$ of them knew that assessment of scene safety is the first thing to do before starting CPR while there was lower knowledge on the more technical skill questions such as the use of the AED (8.3\%) and CPR sequence $(10.8 \%)$.

This result was in agreement with results of study was performed by Alhedaithy et $\mathrm{al}^{23}$ in Saudi Arabia which conducted to medical students and it revealed that (94.3\%) students did not know that checking for pulse should not take more than 10 seconds. Similarly, (94.7\%) students lacked essential 
information about rescue breaths. Also, $89.6 \%$ students did not know that calling for help followed by using an AED then starting $\mathrm{CPR}$ is the right sequence when AED is readily available. On the other hand, majority of the students $(84.5 \%)$ knew that chest compression should be done at a rate not less than 100/minute with $5 \mathrm{~cm}$ depth and that chest should fully recoil between compressions. Also, $80.5 \%$ of the students knew that chest rise was the right way to confirm if air has reached the lungs when doing rescue breaths.

The recent study showed that there was a highly statistical significant difference between mean of pre and post test practice score ( $\mathrm{p}$ value $<0.001$ ) as it was higher in post test $(7.2 \pm 1.6)$ than pre test one $(3.44 \pm 0.85)$ and this was in line with result of a study was done in Karnataka by Ajjappa et al. ${ }^{24}$ who found that the mean pretest score was $(75.09$ $\%)$ and the mean post test score was $(93.17 \%)$ another study was performed by Goswami ${ }^{22}$ in India summarized that the mean of post test practice score $(23.00 \pm 1.18)$ was higher than the mean of pre test practice score (10.31 $\pm 3.84)$.

\section{Study limitation:}

Some teachers refused to participate in the study due to their work in teaching but this was overcome by conduction of the study during their free time. Absence of the equipment for application of Basic Life Support when needed within the schools such as mouth mask and AED so, it is recommended to make it available in the school.

\section{Conclusion:}

The present Basic Life Support (BLS) teaching program was successful in enhancing the knowledge and practice of preparatory school teachers and providing them with the basic information and skills which necessary for resuscitation of any victim with cardiac arrest. The current study recommended preparation of national training materials and clinical guidelines for teachers and students to improve their knowledge about BLS. Conduct practical BLS training sessions regularly for both teachers and students in all schools. Providing the equipment which are needed or BLS within the schools is of the utmost importance.

Fund: No fund was received.

Conflict of interest: There is no conflict of interest.

Acknowledgment: The authors would like to thank the participants for their co-operation to accomplish this work. 


\section{References:}

1. Masih S, Sharma R, Kumar A. Primary school teachers' knowledge and practice regarding first aid management for children. International Journal of Medicine and Public Health 2014; 4 (4) : 158-163.

2. Dwood S, Al-Mosawi H, Khudhair A et al. Evaluate of effectiveness of planned teaching programmer regarding basic life support (BLS) among Nursing Staff in Basra General Hospital. Int $\mathbf{J}$ Nurs. 2014;1(2):155-66.

3. Lloyd-Jones D, Adams R, Brown T, et al. Executive summary: heart disease and stroke statistics: a report from the American Heart Association. Circulation $.2010 ; 121(7): 948$.

4. Ackerman M, Atkins D, Triedman J. Sudden cardiac death in the young. HHS Public Access 2016. 133(10): 1006-1026. doi10.1161/CIRCULATIONAHA.115.02 0254

5. Lotfi K, White L, Rea T, et al .Cardiac arrest in schools. Circulation. 2007; 116(12): 13749[DOI] $[$ PubMed].

6. Hazinski M, Markenson D, Neish S, et al. Response to cardiac arrest and selected life-threatening medical emergencies: the medical emergency response plan for schools: A statement for healthcare providers, policymakers, school administrators, and community leaders. Circulation. 2004; 109(2): 27891[DOI][PubMed]

7. Andersen J, Courson R, Kleiner D et al. National Athletic Trainers' Association Position Statement: Emergency Planning in Athletics. J Athl Train. 2002; 37(1): 99104[PubMed]

8. Fernandes J, Leite A, Auto B, et al. Teaching basic life support to students of public and private high schools. Arquivos Brasileiros de Cardiologia.2014; 102(6):593-601.

9. Gates S, Quinn T, Deakin C,et al. Mechanical chest compression for out of hospital cardiac arrest: Systematic review and meta-analysis. Resuscitation 2015;1.(94):91-97.

10. Cave D, Aufderheide T, Beeson J, et al. Importance and implementation of training in cardiopulmonary resuscitation and automated external defibrillation in schools: a science advisory from the american heart association.

Circulation.2011; 123(6):691-706.

11. McNally B, Robb R, Mehta M, et al. Outof hospital cardiac arrest surveillance --- 
Cardiac Arrest Registry to Enhance Survival (CARES), United States. MMWR Surveill Summ 2011; 60(8):1-19.

12. Ghrayeb F, Amro N ,Rahseed O, et al. Knowledge and attitude of basic life support (BLS) among school teachers in Hebron, Palestine. : International Journal of Research in Medical Sciences. Int J Res Med Sci. 2017;5(6):2477-2482.

13. Rahmati H, Yaghoubinia F, et al. Comparing the Effect of Lecture-Based Training and Basic Life Support Training Package on Cardiopulmonary Resuscitation Knowledge and Skill of Teachers. , Health Scope. 2017;6(3):e15165.

14. Safari M, Yazdanpanah B, Ghafarian H et al. Comparing the effect of lecture and discussion methods on students learning and satisfaction. Iran J Med Educ. 2006; 6(1)PP : 59-64

15. Fahmy S, Nofal L, Shehata $S$, et al. Updating indicators for scaling the socioeconomic level of families for health research. The Journal of the Egyptian Public Health Association .2015;90(1):17.

16. Yunus M , Mishra A, Karim H, et al. Knowledge, attitude and practice of basic life support among junior doctors and students in a tertiary care medical institute International Journal of Research in Medical Sciences. Int J Res Med Sci.2015; 3(12):3644-3650.

17. Alharbi M, Horaib Y, Almutairi Y. Exploring the extent of knowledge of CPR skills among school teachers in Riyadh, KSA. J Taibah Univ Med Sci.2016;11(5):497-501.

18. Al Enizi B, Saquib N, Zaghloul M. Knowledge and attitudes about basic life support among secondary school teachers in Al- Qassim, Saudi Arabia. Int J Health Sci. 2016;10 (3):415-22.

19. Lockey A, Barton K, Yoxall H. Opportunities and barriers to cardiopulmonary resuscitation training in English secondary schools. Eur J Emerg Med.2016;23(5): 381-5.

20. Onyeaso A.Knowledge of Cardiopulmonary Resuscitation among Some Secondary School Students in Nigeria. Journal of Education and Practice.2014;(5):180-183.

21. Kabina $R$.Evaluate the effectiveness of Planned Teaching Programme regarding Basic Life Support among intern students at Selected Nursing College, Bhubaneshswar, odisha. OSR Journal of 
Nursing and Health Science.2014; 2320 1940 ( 3), 1:16-19.

22. Goswami R, Kanika, Sembian N . Effectiveness of Training Program on Knowledge and Practices Regarding Basic Life Support (BLS) Among Nursing Students. Int J Clin Anesthesiol .2015; 3(2): 1046.

23. Alhedaithy A, Almutairi A, Mohammad A, et al. Knowledge and Attitude of the Undergraduate Medical and Health Care Students Towards Basic Life Support in
Saudi Arabia International Journal of Academic Scientific Research 2016;4(4):97-103 .

24. Ajjappa A, Babu C, Gowda S, et al. Effectiveness of BLS Training in improving the Knowledge and skills among Medical Interns J Educational Res \& Med Teach 2015;3(1):28-30. 
Table (1): Socio-demographic characteristics of the participants

\begin{tabular}{|c|c|c|}
\hline Items & Total & Percent \\
\hline Age $\quad($ Mean \pm SD $)$ & \multicolumn{2}{|c|}{$40.1 \pm 5.7$} \\
\hline $\begin{array}{l}\text { Gender } \\
\text { - } \quad \text { Male } \\
\text { - } \quad \text { Female }\end{array}$ & $\begin{array}{c}239 \\
61\end{array}$ & $\begin{array}{l}79.7 \% \\
20.3 \%\end{array}$ \\
\hline $\begin{array}{c}\text { Residence } \\
\text { - Urban } \\
\text { - Rural }\end{array}$ & $\begin{array}{l}167 \\
133\end{array}$ & $\begin{array}{l}55.7 \% \\
44.3 \%\end{array}$ \\
\hline $\begin{array}{l}\text { Husband's education } \\
\text { - Secondary } \\
\text { - High education }\end{array}$ & $\begin{array}{c}1 \\
299\end{array}$ & $\begin{array}{c}.3 .0 \% \\
99.7 \%\end{array}$ \\
\hline $\begin{array}{l}\text { Wife's education } \\
\text { - Secondary } \\
\text { - High education }\end{array}$ & $\begin{array}{l}138 \\
162\end{array}$ & $\begin{array}{c}45.7 \% \\
54.3 \%\end{array}$ \\
\hline $\begin{array}{l}\text { Husband's work } \\
\text { - No } \\
\text { - Yes }\end{array}$ & $\begin{array}{c}0 \\
300\end{array}$ & $\begin{array}{c}0.0 \% \\
100.0 \%\end{array}$ \\
\hline $\begin{array}{l}\text { Wife's work } \\
\text { - No } \\
\text { - Yes }\end{array}$ & $\begin{array}{c}220 \\
80\end{array}$ & $\begin{array}{l}73.5 \% \\
26.5 \%\end{array}$ \\
\hline $\begin{array}{l}\text { Computer uses } \\
\text { - } \text { Never } \\
\text { - } \text { Sometimes } \\
\text { - } \text { A lot of time }\end{array}$ & $\begin{array}{c}36 \\
350 \\
14\end{array}$ & $\begin{array}{c}12 \% \\
83.3 \% \\
4.7 \%\end{array}$ \\
\hline $\begin{array}{l}\text { Income } \\
\text { - Not enough } \\
\text { - Enough }\end{array}$ & $\begin{array}{c}237 \\
62 \\
1\end{array}$ & $\begin{array}{c}79.0 \% \\
20.7 \% \\
3 \%\end{array}$ \\
\hline $\begin{array}{l}\text { Family size } \\
\text { - } 6 \\
\text { - } \quad 5 \\
\text { - } \quad<5\end{array}$ & $\begin{array}{c}18 \\
272 \\
10\end{array}$ & $\begin{array}{l}6.0 \% \\
90.7 \% \\
3.3 \%\end{array}$ \\
\hline $\begin{array}{l}\text { Socioeconomic status } \\
\text { - Low } \\
\text { - Middle } \\
\text { - High }\end{array}$ & $\begin{array}{c}0 \\
253 \\
47\end{array}$ & $\begin{array}{c}0.0 \% \\
84.3 \% \\
15.7 \%\end{array}$ \\
\hline
\end{tabular}


Table (2): Comparison between the participants' knowledge before and three months after application of BLS educational session

\begin{tabular}{|c|c|c|c|c|c|c|}
\hline $\begin{array}{c}\text { Score of } \\
\text { knowledge }\end{array}$ & \multicolumn{2}{|c|}{ Pre-test } & \multicolumn{2}{|c|}{ Post-test } & & \\
\hline \multirow[t]{2}{*}{ Mean \pm SD } & \multicolumn{2}{|c|}{$2.04 \pm 2.4$} & \multicolumn{2}{|c|}{$10.11 \pm 1.8$} & & \\
\hline & $\mathrm{N}=300$ & $\%$ & $\mathrm{~N}=300$ & $\%$ & $\begin{array}{l}\text { Paired T } \\
\text { test }\end{array}$ & P- value \\
\hline Very poor & 208 & $69.3 \%$ & 0 & $0.0 \%$ & \multirow{6}{*}{46.8} & \multirow{6}{*}{$<0.001 * *$} \\
\hline Poor & 82 & $27.3 \%$ & 0 & $0.0 \%$ & & \\
\hline Average & 6 & $2.0 \%$ & 51 & $17.0 \%$ & & \\
\hline Good & 3 & $1.0 \%$ & 67 & $22.3 \%$ & & \\
\hline Very good & 1 & $0.3 \%$ & 71 & $23.7 \%$ & & \\
\hline Excellent & 0 & $0.0 \%$ & 111 & $37.0 \%$ & & \\
\hline
\end{tabular}

**Highly statistically significant. 
Table (3): Comparison between percentages of correct multiple choice answers before and after training of Basic Life Support (BLS)

\begin{tabular}{|c|c|c|c|c|}
\hline \multirow[t]{2}{*}{ Correct multiple choice answers } & \multicolumn{2}{|l|}{ Pre test } & \multicolumn{2}{|l|}{ Post test } \\
\hline & $N=300$ & $\%$ & $\mathbf{N}=\mathbf{3 0 0}$ & $\%$ \\
\hline $\begin{array}{l}\text { - In case of a cardiac arrest, the first thing } \\
\text { that needs to be done is? }\end{array}$ & 103 & $34.4 \%$ & 267 & $89.0 \%$ \\
\hline - When to call for assistance? & 119 & $39.6 \%$ & 285 & $95.0 \%$ \\
\hline $\begin{array}{l}\text { - In terms of the } \mathrm{CPR}^{*} \text { sequence, what is } \\
\text { true? }\end{array}$ & 31 & $10.3 \%$ & 255 & $85.0 \%$ \\
\hline - Which is true about pulse check? & 48 & $16 \%$ & 246 & $82.0 \%$ \\
\hline $\begin{array}{l}\text { - What is recommended regarding chest } \\
\text { compressions? }\end{array}$ & 40 & $13.3 \%$ & 234 & $78.0 \%$ \\
\hline $\begin{array}{l}\text { - In 1- rescuer CPR compression/ ventilation } \\
\text { rate }(\mathrm{C} / \mathrm{V}) \text { is... }\end{array}$ & 50 & $16.6 \%$ & 210 & $70.0 \%$ \\
\hline - Do you know AED**? & 38 & $12.7 \%$ & 260 & $86.7 \%$ \\
\hline $\begin{array}{l}\text { - What is the correct sequence of action } \\
\text { where an AED is available during cardiac } \\
\text { arrest? }\end{array}$ & 25 & $8.3 \%$ & 198 & $66.0 \%$ \\
\hline $\begin{array}{l}\text { - What is the right place to compress chest } \\
\text { for a person having cardiac arrest? }\end{array}$ & 91 & $30.3 \%$ & 272 & $90.7 \%$ \\
\hline $\begin{array}{l}\text { - How would you know that the air has } \\
\text { entered the lungs? }\end{array}$ & 105 & $35 \%$ & 264 & $88.0 \%$ \\
\hline $\begin{array}{l}\text { - In 2- rescuer CPR compression /ventilation } \\
\text { rate }(\mathrm{C} / \mathrm{V}) \text { is: }\end{array}$ & 59 & $19.7 \%$ & 240 & $80.0 \%$ \\
\hline $\begin{array}{l}\text { - What is the right in case of child about } 13 \\
\text { years who has chocking and there is no } \\
\text { pulse or breathing? }\end{array}$ & 99 & $33 \%$ & 282 & $94.0 \%$ \\
\hline $\begin{array}{l}\text { - What is the right in case of child about } 13 \\
\text { years who has chocking and there is } \\
\text { normal pulse? }\end{array}$ & 70 & $23.3 \%$ & 276 & $92.0 \%$ \\
\hline
\end{tabular}


Table (4): Comparison between the participants' practice before and three months after application of BLS educational program

\begin{tabular}{|c|c|c|c|c|c|c|}
\hline Score of practice & \multicolumn{2}{|l|}{ Pre-test } & \multicolumn{2}{|c|}{ Post-test } & & \\
\hline \multirow[t]{2}{*}{ Mean \pm SD } & \multicolumn{2}{|c|}{$3.44 \pm 0.85$} & \multicolumn{2}{|c|}{$7.2 \pm 1.6$} & & \\
\hline & $\mathrm{N}=300$ & $\%$ & $\mathrm{~N}=300$ & $\%$ & $\begin{array}{ll}\text { Paired } & \text { T } \\
\text { test } & \end{array}$ & $P$ value \\
\hline - Very poor & 188 & $62.7 \%$ & 1 & $0.3 \%$ & \multirow{6}{*}{$\mathbf{5 3 . 5 7}$} & \multirow{6}{*}{$<0.001 * *$} \\
\hline - Poor & 112 & $37.3 \%$ & 17 & $5.7 \%$ & & \\
\hline - Average & 0 & $0.0 \%$ & 0 & $0.0 \%$ & & \\
\hline - Good & 0 & $0.0 \%$ & 151 & $50.3 \%$ & & \\
\hline - Very good & 0 & $0.0 \%$ & 54 & $18.0 \%$ & & \\
\hline - Excellent & 0 & $0.0 \%$ & 77 & $25.7 \%$ & & \\
\hline
\end{tabular}

**Highly statistically significant. 


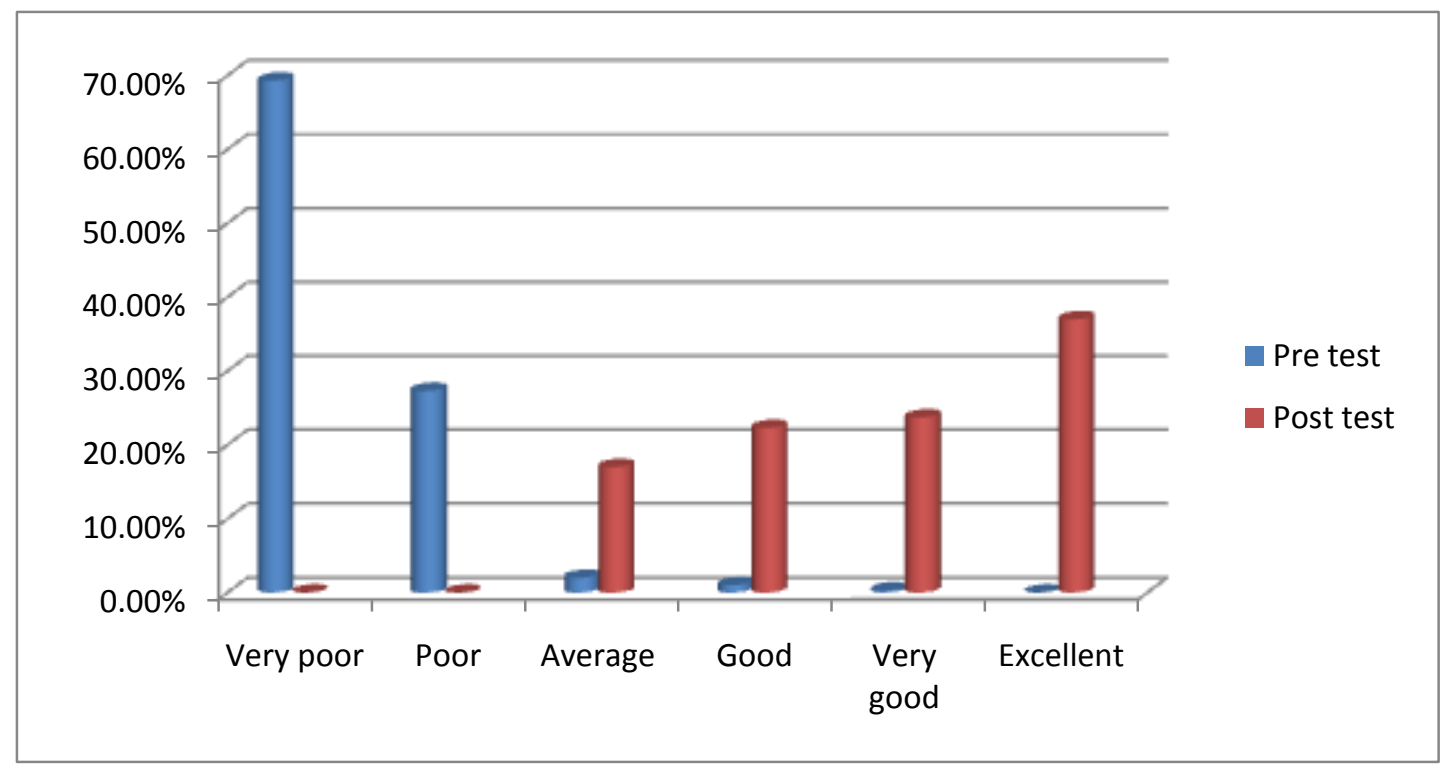

Figure (1): Comparison between percentage of participants' knowledge score before and three months after application of BLS educational program

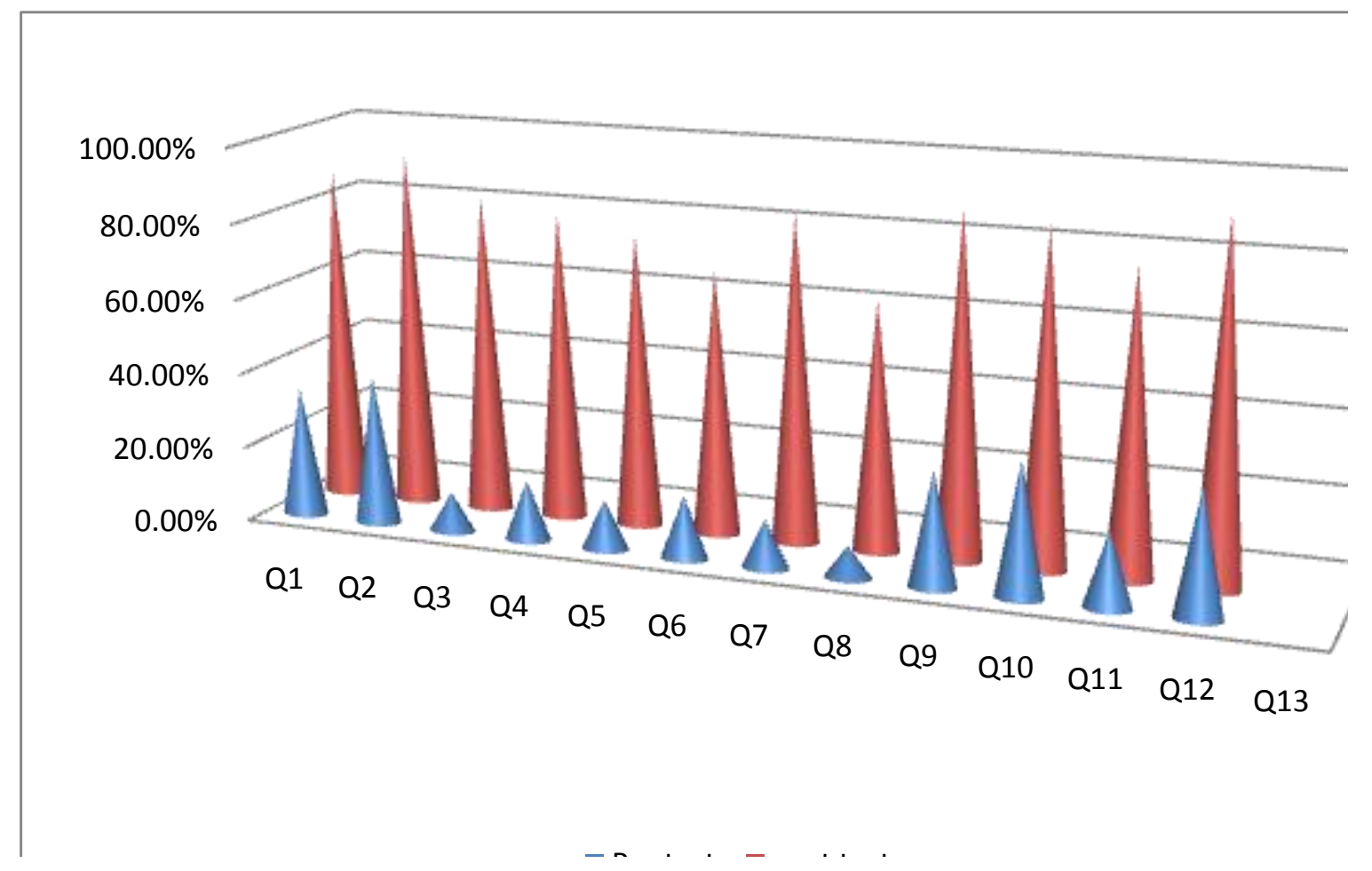

Figure (2): Comparison between percentages of correct multiple choice answers before and after BLS 
الملخص العربى

تأثير التدريب على الدعم الاساسي للحياة على معرفة وممارسة معلمي المدارس الإعدادية ـــدينه شبين الكومـ محافظه. المنوفيه-مصر

صفا حمدي القلش

الخلفية: إن الاكتشاف المبكر و الإنعاش المباثر للرئتين و القلب تعد من العو امل الحاسمة للبقاء على قيد الحياة بعد السكتة القلبية خارج المستشفى. إن وجود المعلمين المؤهلين الذين يمكنهم اكتشـاف أي مشكلة صحية ويمنهم تقديم الإسعافات الأولية لحالات الطوارئ في المدارس يعد مسألة بالغة الأهمية.

الهدف: تقييم معرفة وممارسة معلمي المدارس الإعدادية قبل وبعد تطبيق برنامج تدريبي على دعم الأساسي للحياة في مدينـة شبين الكوم - محافظة المنوفية.

طرق البحث: لقد شـارك في هذه الدر اسـة عينـة من . . ب معلم. تم اختيـار هم من خـلال تقنيـة عينـات عشو ائية بسيطة. وقد أكملو ا

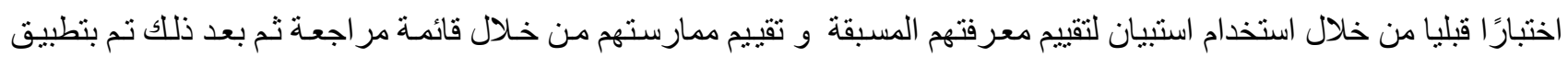
برنامج تدريبي لهم ، واخير ا أعيد تقييم معرفتهم وممارستهم بعد ب أثنهر باستخدام نفس الأدوات المستخدمة مسبقا.

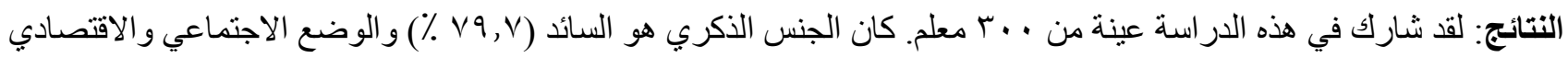

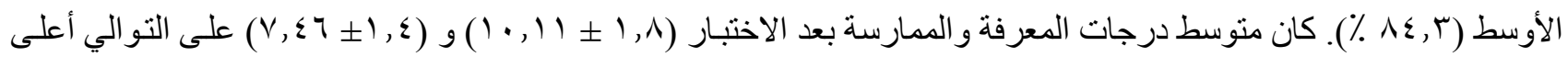

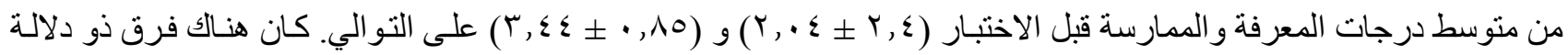
إحصائية في درجات المعرفة و الممارسة قبل وبعد تطبيق برنامج التدريب (قيمة > > > . . . • ) لكل منها. الخلاصة: نجح برنامج التدريب الحالي على الدعم الاساسي للحياة في تعزيز معرفة وممارسة معلمي المدارس الإعدادية. الكلمات المفتاحية: دعم الاساسي للحياة ، المعرفة ، الممارسة و المعلمين. 